\title{
Influence of ethanol and morphine on pain perception evoked by deep tissue injury
}

\author{
Gustavo Hauber Gameiro' ${ }^{1 *}$, Mariana Trevisani Arthuri' ${ }^{1}$ Cláudia Herrera Tambeli ${ }^{1,2}$ Maria Cecília \\ Ferraz de Arruda Veiga ${ }^{1}$
}

${ }^{1}$ Laboratory of Orofacial Pain, Department of Physiology, Faculty of Dentistry of Piracicaba, University of Campinas, São Paulo, ${ }^{2}$ Department of Oral and Maxillofacial Surgery, University of California, San Francisco

*Correspondence:

G. H. Gameiro

Laboratory of Orofacial Pain

Department of Physiology

Faculty of Dentistry of Piracicaba

University of Campinas - Unicamp

Av. Limeira, 901 C.P. 52

13414-900 - Piracicaba - São Paulo

E-mail: ggameiro@fop.unicamp.br
The aim of this study was to evaluate the effect of ethanol and morphine on nociceptive behavioral responses evoked by the injection of formalin into the temporomandibular joint region of rats (the TMJ formalin test). In experiment 1, animals were given an ethanol solution (6.5\%) or tap water to drink for 4 and 10 days, before the procedure for TMJ pain. In the group treated for 4 days, significant analgesia was observed in the TMJ formalin test, whereas the group treated for 10 days did not show this effect, revealing the development of tolerance to ethanol antinociceptive effects. In experiment 2, animals were submitted to chronic regimen of ethanol (6.5\% for 10 days) and the control group was given tap water to drink. After this period, morphine (10 mg/kg i.p.) was administrated 30 minutes before the TMJ formalin test. Morphine had the same analgesic effect in both groups, showing that the treatment with ethanol was not able to alter the analgesic potency of morphine. The results showed that ethanol can affect nociceptive behavioral responses related to pain from deep tissues, like the $T M J$, and the absence of interaction between ethanol and morphine suggest that ethanol-induced analgesia was mediated by nonopiate mechanisms.

\section{INTRODUCTION}

Ethanol and opioids interfere diferentially with transmission processes in the central nervous system (CNS), affecting many of the known neurotransmitter systems (Vasconcelos et al., 2003). Morphine, the main effective substance in opium, has been used as a potent analgesic in clinical practice and is still the primary analgesic for severe pain. Unfortunately, opioids have adverse side effects, including constipation, nausea and respiratory depression, which limit their use. Moreover, the users readily develop tolerance and dependence to opioids (Ikeda et al., 2002).

Ethanol affects many functions of the CNS, resulting in analgesia, sedation, hypnosis, motor disturbance, memory disturbance, confusion, neurodegeneration, and/
Uniterms:

- Ethanol

- Morphine

- Formalin test

- Temporomandibular joint 
or dependence (Deitrich et al., 1989; Fadda, Rossetti, 1998). Ethanol-induced analgesia has been reported in both humans (Cutter, O'Farrel, 1987; Woodrow, Eltherington, 1988) and animals (Bass et al., 1978; Brick et al., 1976; Pohorecky, Shah, 1987; Yirmiya, Taylor, 1989). Previous research evaluated nociception using typical cutaneous pain models such as tail-flick (Jorgensen, Hole, 1981) and foot-shock (Friedman et al., 1980). Our study shows the effects of ethanol and morphine on pain response evoked by deep stimuli, different from the one evoked by superficial stimuli. A particular feature of deep pain conditions is the considerable convergence of cutaneous, visceral, muscle, or joint afferents of spinal as well as trigeminal somatosensory neurons transmitting deep nociceptive information (Sessle, Hu, 1991). Moreover, studies in animals models of persistent pain at spinal levels indicate that peripheral tissue or nerve injury induces a state of hyperexcitability that participates in the development of persistent pain and hyperalgesia (Dubner, 1991; Woolf 1983). In relation to the orofacial region, Iwata et al. (1999) demonstrated that TMJ inflammation resulted in more robust changes in medullary dorsal horn nociceptive neurons as compared with perioral inflammation. Thus, considering that the nociceptive behavioral responses elicited by the injection of formalin into the TMJ represent a valid and reliable model of deep orofacial pain (Roveroni et al., 2001), the purpose of this study was to evaluate the effect of ethanol and morphine on the pain responses induced by TMJ formalin test. Information on the extent of ethanol-induced changes in nociceptive systems can be of clinical value, especially in individuals who regularly drink alcohol and suffer from some kind of chronic pain conditions, like temporomandibular disorders.

\section{MATERIAL AND METHODS}

\section{Animals}

Male Wistar rats (obtained from Centro Multiinstitucional de Bioterismo-Cemib, Unicamp, Campinas, Brazil) weighing 200-300 g served as subjects. The rats were housed individually and maintained on a 12L:12 D cycle (light onset at 07:00 h) in a temperature-controlled room $\left(23 \pm 1{ }^{\circ} \mathrm{C}\right)$. The study was conducted in accordance with the ethical guidelines for investigations of experimental pain in conscious animals (Zimmermann, 1983).

\section{Procedure: Ethanol administration}

Rats ( $N=6 /$ group) were given either an ethanol solution, as their sole drinking solution, or tap water for 4 or
10 days (according to experiments). The ethanol drinking solution was mixed to a $6.5 \%$ concentration using $99.5 \%$ ethanol and tap water (Gatch, Lal, 1999; Bell et al., 1998). Pretreatment was carried out in the animals' home cages. On day 4, one group was taken from the vivarium to the test room and submitted to the TMJ formalin test. In another group, the nociception assay was accomplished 10 days after ethanol or water consumption (control group) to evaluate the development of tolerance to antinociceptive effects of chronic ethanol. Blood ethanol concentrations remain elevated throughout chronic administration when this concentration of ethanol solution is used (Shah et al., 1997).

\section{Morphine test}

Animals were submitted to chronic regimem of ethanol (6.5\% for 10 days) and the control group was given tap water to drink. After this period, morphine $10 \mathrm{mg} / \mathrm{kg}$ (Bell et al., 1998) was injected IP 30 minutes before the procedure for TMJ pain.

\section{Testing procedure for TMJ pain}

The design of this study follows the design used by Roveroni et al. (2001). Testing sessions took place between 08:00 and 13:00 $\mathrm{h}$ in a quiet room mantained at 23 $\pm 1{ }^{\circ} \mathrm{C}$. Each animal was first placed in a test chamber $(30$ $X 30 \times 30 \mathrm{~cm}$ mirrored-wood chamber with glass at the front side) for a $30 \mathrm{~min}$ habituation period to minimize stress (Abbott et al., 1986). After the period of adaptation, the animal was removed from the test chamber and lightly anesthetized by inhalation of halothane to allow the TMJ injection.

Rats received a $50 \mu \mathrm{L}$ injection of diluted formalin $(1,5 \%)$ into the left TMJ region. The injections were performed via a 30 -gauge needle introduced into the TMJ capsule. A cannula consisting of a polyethylene tube was connected to the needle and also to a Hamilton syringe $(50 \mu \mathrm{L})$ previously filled with formalin $1.5 \%$. The lower border of the zigomatic arch was palpated and the needle was introduced in direction to the lateral region of condyle (Figure 1).

Following the TMJ injection, the rat immediately recovered from the anesthesia and was returned to the test chamber for a 45 min observation period ( 15 blocks of $3 \mathrm{~min}$ ). For each block of $3 \mathrm{~min}$, the behavior characterized by rubbing the orofacial region was quantified by the amount of time that the animal exhibited it and the behavior characterized by flinching the head was quantified by its occurrence (number of head flinches). Considering that the flinching of the head behavior followed a uniform pattern 
of $1 \mathrm{~s}$ in duration, each flinching was expressed as $1 \mathrm{~s}$. The combination (sum) of both behaviors provides a better measure of pain intensity than any single behavior (Roveroni et al., 2001). An investigator who was blind to the rat's group assignment made the analysis of the behaviors.

After the conclusion of each experiment, Evans blue dye $(1 \%, 5 \mathrm{mg} / \mathrm{kg})$ was injected systemically in order to confirm the TMJ injection site at post-mortem, as previously described (Haas et al., 1992) by the visual examination of formalin-induced plasma extravasation of Evans blue dye bond to plasma protein.

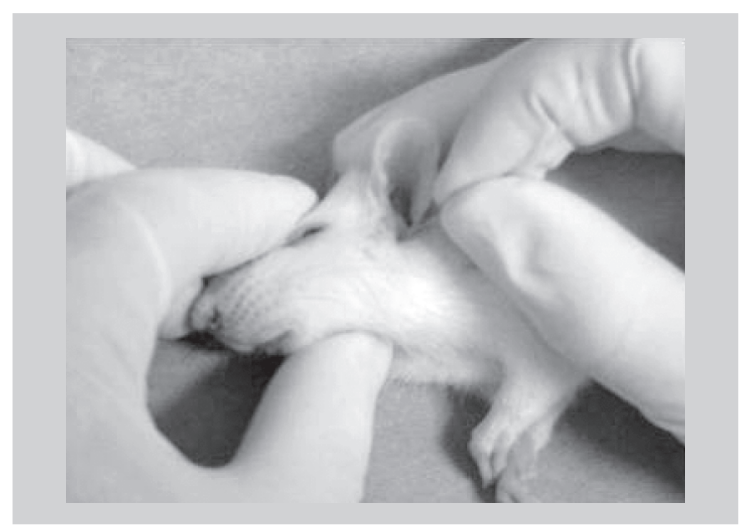

FIGURE 1 - Punction local for formalin administration.

\section{Drugs}

Ethanol (99.5\%) was mixed with water for a concentration of $6.5 \%(\mathrm{v} / \mathrm{v})$. Morphine sulfate was dissolved in isotonic saline and delivered in a volume of $1 \mathrm{~mL} / 100 \mathrm{~g}$ of body weight. Evans blue dye was dissolved in isotonic saline for a concentration of $1 \%$. All drugs were obtained from Sigma, São Paulo, Brazil.

\section{Data Analysis}

The sum of rubbing and flinching responses exhibited by each animal was computed. Parametric tests [ $t$-test and ANOVA (analysis of variance)] were employed, as appropriate. All values are given as mean \pm standard deviation (SD). A level of 5\% was taken as evidence of statistical significance. Body weight, water and ethanol consumption were analyzed by repeated measures ANOVA and polynomial regression. Data were analyzed using SAS (version 8.2 for windows) by Institute Inc., Cary, NC, USA-licensed to Universidade Estadual de Campinas.

\section{RESULTS}

\section{Body Weight and Fluid Consumption}

Figure 2 presents body weight and fluid consumption over the course of 4 - day access to $6.5 \%$ ethanol. Although there was a significant increase in body weight over days $[\mathrm{F}=18.06, p<0,0001$ (Figure $2 \mathrm{~A}$ )], there was no effect of ethanol treatment on body weight $(\mathrm{F}=0.01$, $p=0.9095$ ) and no significant interaction between days and treatment $(\mathrm{F}=1.73, p=0.1825)$. There was no effect of ethanol treatment on fluid consumption $(\mathrm{F}=2.29, p=0.1613)$ and no significant interaction between days and treatment $[\mathrm{F}=0.11, p=0.9562$ (Figure 2B)].

Figure 3 presents body weight and fluid consumption over the course of 10-day access to $6.5 \%$ ethanol. Although there was a significant increase in body weight over days $[\mathrm{F}=79.06, p<0,0001$ (Figure $3 \mathrm{~A}$ )] there was no effect of ethanol treatment on body weight $(\mathrm{F}=0$, $p=0.9533$ ) and no significant interaction between days and treatment $(\mathrm{F}=0.86, p=0.5633)$. There was no effect of ethanol treatment on fluid consumption $(\mathrm{F}=0.59, p=04585)$

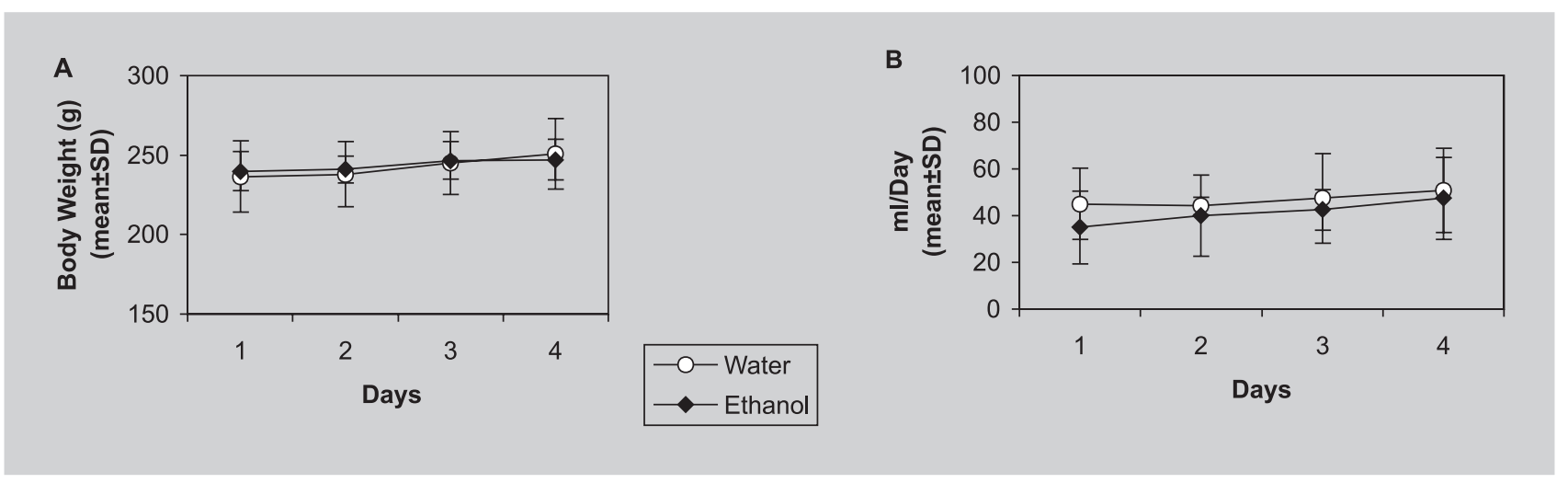

FIGURE 2 - The effect of ethanol drinking on body weight and fluid consumption. Rats had forced access (24 h/day) to water or ethanol $(6.5 \% \mathrm{v} / \mathrm{v})$ for 4 days. A - mean \pm SD daily body weight ( $N=6 /$ group). $\mathbf{B}$ - the amount of water and ethanol consumption per day is presented as $\mathrm{mL} /$ day. 
A

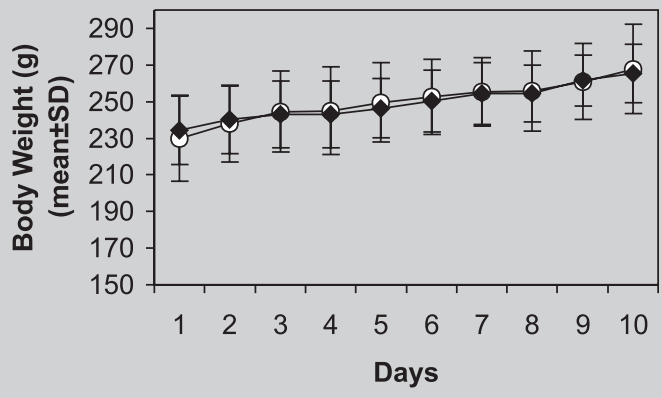

B

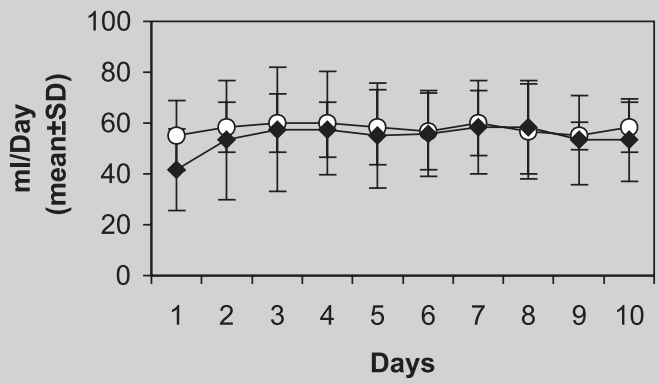

FIGURE 3 - The effect of ethanol drinking on body weight and fluid consumption. Rats had forced access ( $24 \mathrm{~h} /$ day) to water or ethanol $(6.5 \% \mathrm{v} / \mathrm{v})$ for 10 days. A - mean \pm SD daily body weight ( $N=6 /$ group). $\mathbf{B}$ - the amount of water and ethanol consumption per day is presented as $\mathrm{mL} /$ day.

and no significant interaction between days and treatment $[\mathrm{F}=0.21, p=0.9930$ (Figure 3B) $]$.

\section{Effects of Chronic Ethanol Administration}

The antinociceptive effects of ethanol (6.5\% in drink solutions) were apparent by the fourth day of exposure to ethanol solution. The reduction of pain responses was statistically significant $(p<0.001, t$-test; Figure 4$)$ when the control group $(219.48 \pm 40.148)$ was compared with the experimental group $(122.36 \pm 45.48)$.

By day 10, the sum of nociceptive behaviors in the TMJ formalin test was not significantly different between control $\mathrm{X}$ test group, revealing that tolerance to the antinociceptive effects of ethanol has been developed

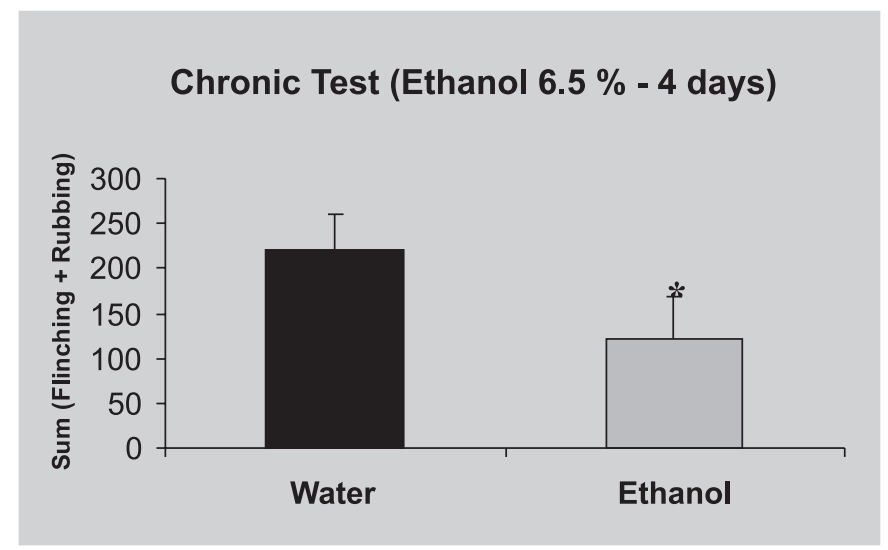

FIGURE 4 - Sum of nociceptive behaviors in the TMJ formalin test after 4 days of drinking an ethanol solution $(N=6)$ or water $(N=6)$. Each column represents the mean. Errors bars indicate the SD. Single asterisk indicates significant difference between the experimental and water control group ( $p<0.001, t$-test $)$.
( $p=0.98, t$-test, Figure 4$)$. The values of control group $(171,07 \pm 39,35)$ were comparable with the test group $(170,71 \pm 43,15$; Figure 5).

\section{Morphine test}

Analysis of simple main effects of baseline behavior (formalin) vs. postdrug behavior (formalin + morphine) revealed that morphine produced significant analgesia in both groups [water pretreatment: baseline $(171.07 \pm 39.24)$ vs. postdrug (13.96 \pm 19.68$)$; ethanol pretreatment: baseline $(170.71 \pm 43.146)$ vs. postdrug $(14.29 \pm 10.79)-p<0.001$ Oneway ANOVA + Tukey, Figure 6]. No significant differences were found between postmorphine behaviors, indicating that the rats did not develop cross-tolerance

\section{Chronic Test (Ethanol $6.5 \%$ - 10 days)}

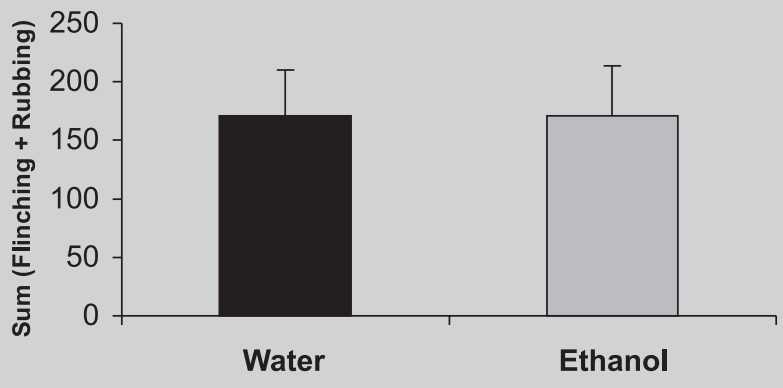

FIGURE 5 - Sum of nociceptive behaviors in the TMJ formalin test after 10 days of drinking an ethanol solution $(N=6)$ or water $(N=6)$. Each column represents the mean. Errors bars indicate the SD. No significant differences were found in pain responses for animals pretreated with ethanol vs. water ( $p=0.98, t$-test). 


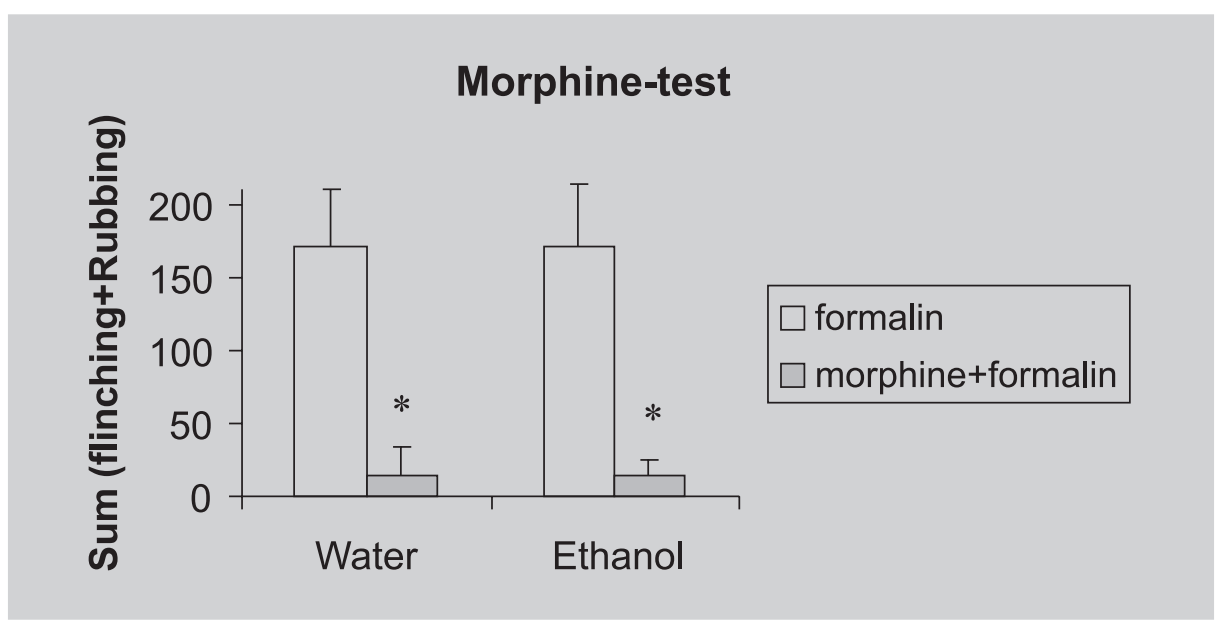

FIGURE 6 - Analgesic effect of morphine $(10 \mathrm{mg} / \mathrm{kg}$, IP) in the TMJ formalin test after ten days of drinking an ethanol solution $(N=6)$ or tap water $(N=6)$. Data are expressed as the mean of the sum of nociceptive behaviors SD. $*$ indicates significant differences from baseline (formalin) nociceptive behaviors.

between ethanol-induced analgesia (EIA) and morphineinduced analgesia (MIA).

\section{DISCUSSION}

Alteration in the perception of pain can be produced by either environmental or pharmacological manipulations. In an early study, ethanol was found to attenuate naloxoneinduced hyperalgesia (Bass et al., 1978), suggesting a possible interaction between EIA and the endogenous opioid systems. Ethanol-opiate interactions have also been addressed by examining cross-tolerance between EIA and MIA. Jorgensen and Hole (1984) found that neither tolerance to EIA nor cross-tolerance to MIA developed in rats injected with $2.5 \mathrm{~g} / \mathrm{kg}$ ethanol for 8 days. However, tolerance to EIA accompanied by cross-tolerance to MIA was found if the animal were exposed to the analgesic test (i.e., tail-flick) during tolerance induction (Jorgensen et al., 1986). This tolerance is called "associative" or "environment-dependent" tolerance. Although some studies have shown that tolerance to ethanol's effects can be reduced or eliminated if animals are tested in an environment that is different from that which was used to induce tolerance (Jorgensen, Hole, 1984; Gatch, Lal, 1999; Jorgensen et al., 1986), Bell et al. (1998) showed that tolerance to antinociceptive effect of ethanol can be induced in rats using both non-associative (selfadministration) and associative (IP injections) paradigms. They also support that EIA was nonopioid in nature, as neither form of ethanol tolerance was accompanied by cross-tolerance to MIA. Inversely, Shah et al. (1997) demonstrated that ethanol consumption decreases the analgesic potency of opioids in mice through a mechanism that is unrelated to pharmacokinetics or opioid receptor changes in brain and cord. The study of Duttaroy et al. (1998) showed that chronic forced ethanol drinking can decrease the analgesic potency of opioid agonists in mice, and this effect may be produced via alterations in Gprotein-coupled intracellular mechanisms. The reason for these discrepancies should be related to a number of factors including species-related differences (Boada et al., 1981; Fidecka et al., 1986; Jorgensen, Hole, 1981), and the test used to measure opiate-ethanol interactions (Khanna, Lê, 1996). Our data show that tolerance to EIA was induced by pharmacological rather than behavioral factors, because the tolerance induction procedure was carried out in the rat's cages and the TMJ formalin test in another room, after a habituation period to minimize stress (Abbott et al., 1986). Furthermore, the results of this study do not support an ethanol-opiate interaction for EIA, as ethanol tolerance was not accompanied by cross-tolerance to MIA, indicating that ethanol's analgesic effects on TMJ formalin test is mediated by nonopiate mechanisms.

The mechanism though which ethanol produces antinociception is not clear; in fact, more than one mechanism could be involved. Ethanol has NMDA antagonist properties as supported by electrophysiological (Lovinger et al., 1989), biochemical (Hoffman et al., 1989), and behavioral studies (Kosten, Bombace, 2001). Grant (1999) reported that ethanol can also act as positive modulator of $\mathrm{GABA}_{\mathrm{A}}$ receptors, enhancing GABAactivated flow of $\mathrm{Cl}$; lower training doses of ethanol can enhance the 5HT-effect on $5 \mathrm{HT} 1 \mathrm{~B} / 2 \mathrm{c}$ receptors, which are situated basically in inhibitory interneurones. Gruss et 
al. (2001) suggested that the activation of largeconductance calcium-activated $\mathrm{K}+$ channels $(\mathrm{BK}(\mathrm{Ca})$ channels) induced by clinically relevant concentrations of ethanol might contribute to ethanol-induced analgesia. Ethanol inhibits current responses mediated by ATP receptor channels designated as $\mathrm{P} 2 \mathrm{X}$ receptors (Li et al., 1994; Weight et al., 1994). Among the various targets of ethanol, G protein-activated inwardly rectifying potassium (GIRK) channels are the only molecules whose involvement in ethanol-induced analgesia has been demonstrated in vivo (Ikeda et al., 2001).

Since most of the molecules mediating ethanol effects are the same associated with the modulation of pain arising from deep tissues, for example, GABA $-\mathrm{R}$ (Kenji et al., 2001), GIRK (Ikeda et al., 2001), NMDA receptors (Yu et al., 1996), 5HT-receptors (Garraway, Hochman, 2001) and ATP-R (Hu et al., 2002), its possible that ethanol can influence nociceptive mechanisms related to deep tissue injuries, which have characteristics different from those related to cutaneous injuries (Sessle, $\mathrm{Hu}, 1991$ ).

In the present study, we also used systemic morphine administration to evaluate the interaction between ethanol and opioids on the pain perception evoked by TMJ formalin test. Morphine significantly reduced the formalin-induced rubbing and flinching responses at a concentration of $10 \mathrm{mg} / \mathrm{kg}$, the same used in the study of Bell et al. (1998). The analgesic potency of morphine was the same in animals pretreated either with water or ethanol, revealing that ethanol was not able to decrease the effectiveness of morphine. The absence of cross-tolerance between EIA and MIA suggest that the mechanisms of ethanol's analgesic effects are nonopiate in nature on the TMJ formalin test.

The formalin test (Roveroni et al., 2001; Dubuisson, Dennis, 1977) is a commonly used model of tonic and inflammatory pain. Because it models naturally-occuring painful stimuli, it is more relevant to clinical pain and more sensitive to the effects of analgesic drugs than phasic pain models such as the hot-plate or tail-flick (Hammond, 1989). One of the characteristics of the formalin response is its biphasic pattern (Abbott et al., 1995; Clavelou et al., 1995). Whilst the first phase formalin response is mediated by direct afferent stimulation, the second phase behavioral response is dependant on a central hyperexcitability of the recipient second-order dorsal horn neurons (Martindale et al., 2001). Thus, considering that the TMJ formalin test evaluate the later response (Roveroni et al., 2001), we suggest that ethanol's effects on this test are centrally-mediated.

In conclusion, our results show that ethanol can affect nociceptive behavioral responses related to pain from deep tissues, like the TMJ, and the absence of interaction between ethanol and morphine suggest that ethanol's analgesic effect on the TMJ formalin test is mediated by nonopiate mechanisms.

\section{RESUMO}

\section{A influência do etanol e da morfina sobre a per- cepção dolorosa provocada por injúria tecidual profunda}

O objetivo deste estudo foi avaliar o efeito do etanol e da morfina sobre as respostas comportamentais nociceptivas provocadas pelo teste da formalina na ATM de ratos (Teste da formalina na ATM). No experimento 1, os animais receberam uma solução de etanol $6,5 \%$ ou água comum para beber durante 4 e 10 dias, antes da realização do teste da formalina na ATM. No grupo tratado por 4 dias, observou-se analgesia significativa ao teste da formalina, enquanto que no grupo tratado por 10 dias esse efeito não ocorreu, demonstrando o desenvolvimento de tolerância aos efeitos antinociceptivos do etanol. No experimento 2, os animais foram submetidos ao regime crônico de etanol (6,5\% por 10 dias) e o grupo controle recebeu água comum para beber. Após esse periodo, foi administrado morfina (10 mg/kg i.p.) 30 minutos antes da realização do teste da formalina na ATM. A morfina teve o mesmo efeito analgésico nos 2 grupos, demonstrando que o tratamento com etanol não foi capaz de alterar a potência analgésica da morfina. Os resultados mostraram que o etanol é capaz de alterar as respostas nociceptivas relacionadas à dor proveniente de tecidos profundos, como a ATM, e a ausência de interação entre o etanol e a morfina indica que a analgesia induzida pelo etanol é mediada por mecanismos não-opióides.

UNITERMOS: Etanol. Morfina. Teste da formalina. Articulação temporomandibular.

\section{ACKNOWLEDGMENTS}

The authors thank Professor Jorge Valério for English revision and Gláucia M. B. Ambrosano for statistical analysis. This work was supported by CAPES and FAEP, UNICAMP, Brazil.

\section{REFERENCES}

ABBOTT, F. V., FRANKLIN, K. B. J., CONNELL, B. The stress of a novel environment reduces formalin pain: possible role of serotonin. Eur. J. Pharmacol., Amsterdam, v.126, n.1-2, p.141-144, 1986. 
ABBOTT, F. V., FRANKLIN, K. B., WESTBROOK, R. F. he formalin test: scoring properties of the first and second phases of the pain response in rats. Pain, Amsterdam, v.60, n.1, p.-102, 1995.

BASS, M. B., FRIEDMAN, H. J., LESTER, D. Antagonism of naloxone hyperalgesia by ethanol. Life Sci., Oxford, v.22, n.21, p.1939-1946, 1978.

BELL, R.L., OLSON, R. D., VACCARINO, A. L. Tolerance to ethanol analgesia is not accompanied by cross-tolerance to morphine analgesia in rats. Pharmacol. Biochem. Behav., Oxford, v.59, n.1, p.123127, 1998.

BOADA, J., FERIA, M., SANZ, E. Inhibitory effect of naloxone on the ethanol-induced antinociception in mice. Pharmacol. Res. Commun., New York v.13, n.7, p.673$678,1981$.

BRICK, J., SUN, J. Y., DAVIS, L., POHORECKY, L. A. Ethanol and the response to electric shock in rats. Life Sci., Oxford, v.18, n.11, p.1293-1298, 1976.

CLAVELOU, P., DALLEL, R., ORLIAGUET, T., WODA, A., RABOISSON, P. The orofacial formalin test in rats: effects of different formalin concentrations. Pain, Amsterdam, v.62, n.3, p.295-301, 1995.

CUTTER, H. S. G., O'FARREL, T. J. Experience with alcohol and the endogenous opioid system in ethanol analgesia. Addict. Behav., Oxford, v.12, n.4, p. 331-343, 1987.

DEITRICH, R. A., DUNWIDDIE, T. V., HARRIS, R. A., ERWIN, V. G. Mechanism of action of ethanol: initial central nervous system actions. Pharmacol. Rev., Baltimore, v.41, n.4, p. 489-537, 1989.

DUBUISSON, D., DENNIS, S. G. The formalin test: a quantitative study of the analgesic effects of morphine, meperidine, and brain stem stimulation in rats and cats. Pain, Amsterdam, v.4, n.2, p.161-174, 1977.

DUBNER, R. Basic mechanisms of pain associated with deep tissues. Can. J. Physiol. Pharm., Ottawa, v.69, n.5, p.607-609, 1991.
DUTTAROY, A., GREGORIO, G., SHAH, S., SHEN, J., PHILIPPE, J., MONDERSON, T., YOBURN, B. C. Acute ethanol exposure deceases the analgesic potency of morphine in mice. Life Sci., Oxford, v.62, n.2, p.35-41, 1998.

FADDA, F., ROSSETTI, Z. L. Chronic ethanol consumption: from neuroadaptation to neurodegeneration. Prog. Neurobiol., Oxford, v.56, n.4, p.385-431, 1998.

FIDECKA, S. E., TAMBORSKA, E., MALEC, D., LANGWINSKI, R. The development of cross-tolerance between ethanol and morphine. Pol. J. Pharmacol. Pharm., Warszawa, v.38, n.3, p.277-284, 1986.

FRIEDMAN, H., BASS, M., LESTER, D. Ethanol-induced analgesia in rats selectively bred for ethanol sensitivity. Pharmacol. Biochem. Behav., Oxford, v.13, n.6, p.773$776,1980$.

GARRAWAY, S. M., HOCHMAN, S. Serotonin increases the incidence of primary afferent-evoked long-term depression in rat deep dorsal horn neurons. $J$. Neurophysiol., Bethesda, v.85, n.5, p.1864-1872, 2001.

GATCH, M. B., LAL, H., Effects of ethanol and ethanol withdrawal on nociception in rats. Alcohol. Clin. Exp. Res., Philadelphia, v.23, n.2, p.328-333, 1999.

GRANT, K. A. Strategies for understanding the pharmacological effects of ethanol with drug discrimination procedures. Pharmacol. Biochem. Behav., Oxford, v.64, n.2, p.261-267, 1999.

GRUSS, M., HENRICH, M., KONIG, P., HEMPELMANN, G., VOGEL, W., SCHOLZ, A. Ethanol reduces excitability in a subgroup of primary sensory neurons by activation of $\mathrm{BK}(\mathrm{Ca})$ channels. Eur. J. Neurosci., Oxford, v.14, n.8, p.1246-1256, 2001.

HAAS, D. A., NAKANISHI, O., MACMILLAN, R. E., JORDAN, R. C., HU, J. W., Development of an orofacial modelofacuteinflammationintherat. Arch. Oral Biol., Oxford, v.37, n.5, p.417-422, 1992.

HAMMOND, D. H. Interference of pain and its modulation from simple behaviors. In: Chapman C.R., Loeser J.D.,eds. Advances in pain research and therapy, issues in pain measurement. New York: Raven Press, 1989. p. 69-91. 
HOFFMAN, P. L., RABE, C. S., MOSES, F., TABAKOFF, B. N-methyl-D-aspartate receptors and ethanol :inhibition of calcium flux and cyclic GMP production. $J$. Neurochem., Oxford, v.52, n.6, p.1937-1940, 1989.

HU, B., CHIANG, C. W., HU, J. W., DOSTROVSKY, J. O., SESSLE, B. J. P2X receptors in trigeminal subnucleus caudalis modulate central sensitization in trigeminal subnucleus oralis. J. Neurophysiol. , Bethesda, v.88, n.4, p.1614-1624, 2002.

IKEDA, K., KOBAYASHI, T., KUMANISHI, T., YANO, R., SORA, I., NIKI, H. Molecular mechanisms of analgesia induced by opioids and ethanol: is the GIRK channel one of the keys? Neurosci. Res., Clare, v. 44, n.2, p.121-131, 2002.

IWATA, K., TASHIRO, A., TSUBOI, Y., IMAI, T., SUMINO, R., MORIMOTO, T., DUBNER R, REN K. Medullary dorsal horn neuronal activity in rats with persistent temporomandibular joint and perioral inflammation. J. Neurophysiol., Bethesda, v.82, n.3, p.1244-1253, 1999.

JORGENSEN, H. A., FASMER, O. B., HOLE, K. Learned and pharmacologically induced tolerance to ethanol and cross-tolerance to morphine and clonidine. Pharmacol. Biochem. Be., Oxford, v.24, n.4, p.1083-1088, 1986.

JORGENSEN, H. A., HOLE, K. Does ethanol stimulate brain opiate receptors? Studies on receptor binding and naloxone inhibition of ethanol-induced effects. Eur. J. Pharmacol., Amsterdam, v.75, n.4, p.223-229, 1981.

JORGENSEN, H.A., HOLE, K. Learned tolerance to ethanol in the spinal cord. Pharmacol. Biochem. Behav., Oxford, v.20, n.5, p.789-792, 1984.

KENJI, S., HU, J. W., CAIRNS, B. E., GENJI, S. Involvement of GABAA receptor in modulation of jaw muscle activity evoked by mustard oil application to the rat temporomandibular joint. Brain Res., Amsterdam, v.892, n.1,p.198-202, 2001.

KHANA, J. M., LÊ, A. D. Cross-tolerance: Theoretical and experimental issues. In: BEGLEITER, H.; KISSIN, B., eds. The pharmacology of alcohol and alcohol dependence. New York: Oxford University Press, 1996. p.110-142
KOSTEN, T. A., BOMBACE, J. C. Ethanol enhances naloxone sensitization and disrupts morphine discrimination-comparison to dizocilpine and pentobarbital: explanation of enhancing acute and attenuating chronic effects. Prog. Neuropsychopharmacol. Biol. Psychiatry., Oxford, v.25, n.6, p.12831306, 2001.

LI, C., PEOPLES, R. W., WEIGHT, F. F. Alcohol action on a neuronal membrane receptor: evidence for a direct interaction with the receptor protein. Proc. Natl. Acad. Sci. USA, Washington, v.91, n.17, p.8200 - 8204, 1994.

LOVINGER, D.M., WHITE, G., WEIGHT, F. Ethanol inhibits NMDA-activated ion current in hippocampal neurons. Science, Washington, v.243, n.4899, p.17211724, 1989.

MARTINDALE, J., BLAND-WARD, P. A., CHESSELL, I. P. Inhibition of C-fibre mediated sensory transmission in the rat following intraplantar formalin. Neurosci. Lett., Limerick, v.316, n.1,p.33-36, 2001.

POHORECKY, L. A., SHAH, P. Ethanol-induced analgesia. Life Sci., Oxford, v.41, n.10, p.1289-1295, 1987.

ROVERONI, R. C., PARADA, C. A., VEIGA, M. C. F. A., TAMBELI, C. H. Development of a behavioral model of TMJ pain in rats: the TMJ formalin test. Pain, Amsterdam, v.94, n.2, p.185-191, 2001.

SESSLE, B. J., HU, J. W. Mechanisms of pain arising from articular tissues. Can. J. Physiol. Pharm., Ottawa, v.69, n.5, p.617-626, 1991.

SHAH, S., DUTTAROY, A., SEHBA, F., CHEN, B., PHILIPPE, J., MONDERSON, T., LAU-CAM, C., CARROLL, J., YOBURN, B. C. The effect of ethanol drinking on opioid analgesia and receptors in mice. Alcohol, New York, v.14, n.4, p.361-366, 1997.

VASCONCELOS, S. M. M., MACÊDO, D. S., LIMA, L. O., SOUSA, F. C. F., FONTELES, M. M. F., VIANA, G. S. B., Effect of one-week ethanol treatment on monoamine levels and dopaminergic receptors in rat striatum. Braz. J. Med. Biol. Res., Ribeirão Preto, v.36, n.4, p.503-509, 2003. 
WEIGHT, F. F., LI, C., PEOPLES, R. W. Alcohol action on membrane ion channels gated by extracellular ATP (P2X receptors). Neurochem. Int., Oxford, v.35, n.2, p.143$152,1999$.

WOODROW, R. M., ELTHERINGTON, L. G. Feeling no pain: Alcohol as an analgesic. Pain, Amsterdam, v. 32, p.159-163, 1988.

WOOLF, C. Evidence for a central component of post-injury pain hypersensitivity. Nature, London, v.306, n.5944, p.686-688, 1983.

YIRMIYA, R., TAYLOR, A. N. Genetic differences in opiate receptor concentration and sensitivity to ethanol's effects. Pharmacol. Biochem. Behav., Oxford, v. 33, n.4, p.793796, 1989.
YU, X. M., SESSLE, B. J., HAAS, D. A., IZZO, A., VERNON, H., HU, J. W. Involvement of NMDA receptor mechanisms in jaw electromyographic activity and plasma extravasation induced by inflammatory irritant application to temporomandibular joint region of rats. Pain, Amsterdam, v.68, n.1, p.169-178, 1996.

ZIMMERMANN, M. Ethical guidelines for investigations of experimental pain in conscious animals. Pain, Amsterdam, v.16, n.2, p.109-110, 1983.

Recebido para publicação em 12 de agosto de 2003. Aceito para publicação em 22 de junho de 2004. 